\title{
COMPETING SOVEREIGNTIES: INCREASING TENSIONS OVER THE MARITIME BORDER IN NORTHEAST ASIA
}

\author{
Mihoko Kato* \\ National Institutes for the Humanities, Tokyo; \\ Slavic-Eurasian Research Center, Hokkaido University
}

DOI: 10.20542/2307-1494-2020-1-63-77

\begin{abstract}
The article focuses on relations between Japan and the Republic of Korea and particularly on their dispute over the territorial sovereignty of the Takeshima/Dokdo islands. This dispute has intensified since the late 1990s, after the United Nations Convention on the Law of the Sea came into force and the Northeast Asian countries started to seek delimitation of their maritime boundaries. The author examines how the Takeshima/Dokdo issue has evolved in changing international conditions and in the context of the Japanese-Korean bilateral relations through the lens of those common interests that connect the two countries. Since the late 1990s, Japan and the Republic of Korea have sought to form a maritime order based on joint and peaceful use of marine resources by signing the 1998 fishery agreement. The two parties also signed a military-intelligence agreement in 2015 for the sake of cooperation against the North Korean threat. However, neither of the two agreements has functioned properly due to escalation of the Japan-Republic of Korea row in the 2010s that expanded beyond the Takeshima/Dokdo dispute. The July 2019 air incident involving Chinese and Russian warplanes revealed that the unsettled maritime border issue can trigger competition for sovereignty not only over the islets and marine resources, but also over the airspace and the air defense identification zone, as there is no common legal basis for managing this domain.
\end{abstract}

Keywords maritime border, sovereignty, common interests, Takeshima/Dokdo islands, air defense identification zone, Japan, Republic of Korea, North Korea, China, Russia, the United States

\section{Название Соперничество за суверенитет: рост напряженности вокруг морской границы статьи в Северо-Восточной Азии}

Аннотация В статье рассматриваются проблемы в отношениях между Японией и Республикой Корея и, в частности, их спор относительно территориального суверенитета над островами Такэсима/Токто. Этот спор обострился с конца 1990-х годов, после того, как вступила в силу Конвенция ООН по морскому праву и страны Северо-Восточной Азии стали добиваться делимитации своих морских границ. Автор анализирует эволюцию проблемы Такэсимы/Токто в меняющихся международных условиях и в контексте двусторонних отношений с точки зрения объединяющих две страны общих интересов. С конца 1990-х годов Япония и Республика Корея пытаются сформировать порядок мирного совместного использования морских ресурсов, подписав в 1998 г. соглашение о рыболовстве. В 2015 г. страны также подписали двустороннее соглашение по обмену инфрормацией военного характера с целью сотрудничества в противодействии угрозе, исходящей из Северной Кореи. Ни то, ни другое соглашение, однако, должным образом не действует

\footnotetext{
* Mihoko Kato (Japan) is a Research fellow of National Institutes for the Humanities, Tokyo and a specially appointed assistant professor at the Slavic-Eurasian Research Center, Hokkaido University.

Михоко Като (Япония) - научный сотрудник Национального института гуманитарных наук (Токио) и доцент Центра славянских и евразийских исследований Университета Хоккайдо.
} 
ввиду эскалации напряженности между Японией и Республикой Кореей в 2010-е годы, которая вышла за рамки территориального спора за острова Такэсима/Токто. Произошедший в июле 2019 г. воздушный инцидент с участием китайских и российских самолетов показал, что нерешенная проблема морской границы может спровоцировать соперничество по поводу не только небольших островов и морских биоресурсов, но и контроля над воздушным пространством и зоной идентификации противовоздушной обороны, если он не регулируется общей правовой базой.

Ключевые морская граница, суверенитет, общие интересы, острова Такэсима/Токто, слова зона идентификации противовоздушной обороны, Япония, Республика Корея, Северная Корея, Китай, Россия, США

\section{Introduction}

For the past twenty years, tensions concerning sovereignty over border islands have intensified among Northeast Asian countries. Both Russia and Japan officially claim their sovereignty over the Northern territories/Southern Kuril Islands. While the Republic of Korea (ROK) has controlled Takeshima/Dokdo ${ }^{1}$ since 1954, Japan has criticized the ROK for what it sees as illegal occupation not justified by the international law. Japan itself has controlled Senkakus/Diaoyu since 1972 and does not acknowledge any issue of territorial sovereignty, while China and Taiwan challenge the Japanese sovereignty over the islets. In addition to these long-lasting problems, in early 2020, Russia"s Ministry of Foreign Affairs informed to the media that the Federal Council"s foreign relations committee, along with the Ministry of Foreign Affairs, the Ministry of Agriculture, and the Federal Security Service, discussed implications of the 1990 Soviet-U.S. Treaty on the maritime boundary in the Bering Sea that has been enforced provisionally in the absence of ratification by the USSR/Russia. ${ }^{2}$ These cases demonstrate that the maritime boundary disputes involving the United States, Russia, China, Taiwan, the ROK, and Japan are still unsettled in the area extending from the Bering Sea through the Sea of Okhotsk and the Sea of Japan to the East China Sea. How do these unsettled disputes over maritime territorial sovereignty affect the evolving international order in Northeast Asia?

According to Hedley Bull, "international order" means a pattern of activity that sustains the elementary or primary goals of the community of states. The community of states (international society) exists when a group of states, conscious of certain common interests and common values, form a society in the sense that they conceive themselves to be bound by a common set of rules in their mutual relations and partake in the work of common institutions. ${ }^{3}$ In his explanation, the term "sovereignty" has been used in two different ways. ${ }^{4}$ Domestically, states assert internal sovereignty that means supremacy over all other authorities within a particular territory and a segment of the human population. Internationally, states assert external sovereignty that means not supremacy but independence from outside authorities. In this article, the author mainly deals with external sovereignty.

The article examines how a territorial dispute has evolved in the changing relations between two countries, from the perspective of common interests, with the Takeshima/Dokdo issue and the Japan-ROK relations used as examples. The Takeshima/Dokdo issue is not merely a dispute over territorial sovereignty between Japan and ROK, but is also relevant to a wide range of regional issues, such as fishery, rise of nationalism, historical perceptions, and military-security cooperation. Since the 
end of World War II through the present time, most Northeast Asian countries have had some interests related, in one way or another, to the context of the Takeshima/Dokdo issue. Section II focuses on the historical background of the unresolved Takeshima/Dokdo issue from the early twentieth century to the conclusion of the Treaty on Basic Relations between Japan and the ROK in 1965. Section III discusses the resurgence of a territorial sovereignty dispute over Takeshima/Dokdo in the context of delimiting the maritime boundaries of Exclusive Economic Zones (EEZ) in the late 1990s. This section also pays attention to when and how the territorial issue is connected with nationalistic discourse. The fourth section examines why the Takeshima/Dokdo issue has gained public visibility and has become a symbol of confrontation between Japan and the ROK in the 2010s, against the background of divergent historical perceptions and increased tensions over the North Korean issue. Section $V$ analyses the impacts of the Japan-ROK confrontation on the regional security order by looking at the July 2019 incident with Russian and Chinese bombers.

\section{Historical background ${ }^{5}$}

The Takeshima/Dokdo archipelago consists of two main islands (Ojima/Seodo and Mejima/Dongdo) and the surrounding rocks and is situated $217 \mathrm{~km}$ to the east from the ROK's mainland and $211 \mathrm{~km}$ to the west from the Japanese mainland. Before the group of islets came under effective governmental control, local people went in for fishing and hunting for sea lions. Today, both Japan and ROK claim their historical rights for the group of islets. At present, the ROK exercises effective control of Takeshima/Dokdo that has approximately 40 residents including 35 ROK"s police personnel. ${ }^{6}$ While the government of the ROK denies the very existence of the territorial dispute and rejects any diplomatic negotiations or judicial settlement on the matter, the Japanese government also claims territorial sovereignty over the islets and seeks the settlement of the dispute on the basis of the international law.

In January 1905, while in a state of war with Russia, Japan decided to incorporate Takeshima to the Shimane prefecture by a cabinet decision. On 22 February 1905, this decision came into force. As a result of the Russian-Japanese war, Japan"s exclusive political, military, and economic interests were acknowledged by the Russian Empire in the Treaty of Portsmouth signed in September 1905. A series of events, starting from the incorporation of Takeshima/Dokdo to the Shimane prefecture in 1905 and resulting in the Japanese annexation of Korea in October 1910, is deeply rooted in the Korean historic memory.

After the Japanese rule ended in August 1945, the Republic of Korea was founded in August 1948 and the Democratic People"s Republic of Korea (DPRK) was established a month later. The allied General Headquarters (GHQ) imposed limitations on Japan"s fishery industry and whaling by establishing the MacArthur Line in the waters surrounding Japan. This meant that under the GHQ rule Japan was not permitted fishing based on the Mare Liberum (The Freedom of the Seas). The GHQ"s concern was that development and re-expansion of Japanese fishery industry would provoke Japan"s rearmament. ${ }^{7}$

Japan restored its national sovereignty and the MacArthur Line was abolished when the Treaty of San Francisco came into force on 28 April 1952. Abolishment of the MacArthur Line implied that Japan would resume fishery in high seas all over the world. This was perceived as a threat by some other fishing countries. For instance, after the Treaty of San Francisco was concluded in October 1951, the ROK demanded that Japan agree to a bilateral fishery agreement. However, Japan did not respond to the demand. ${ }^{8}$ In response, the government of ROK unilaterally declared the Syngman Rhee Line on 
18 January 1952 in an attempt to claim its sovereignty over the high seas contiguous to internationally accepted ROK territorial waters (at that time limited to three nautical miles zone). The line left the Takeshima/Dokdo islands on the Korean side, but neither the Japanese government, nor the GHQ did recognize it. The government in Seoul started to implement de facto control of Takeshima/Dokdo since January 1954 by dispatching Coast Guards to the islets. ${ }^{9}$ Since then, the ROK security agency has been stationed in the area. In a period from adoption of the Rhee declaration until its abandonment in 1965, 328 fishing vessels were captured, 3929 crew members were detained, and 44 were killed or injured by the ROK"s security agency. ${ }^{10}$

As a result of long negotiations that lasted since October 1951, Japan and the ROK signed the Treaty on Basic Relations in June 1965. The ROK effectively used captured vessels and detained crews as a diplomatic card in negotiations. The Japanese government abandoned its rights to claim property in the Korean Peninsula and agreed to grant the ROK $300 \mathrm{mln}$ USD and to provide $200 \mathrm{mln}$ USD more as a long-term low-interest loan. In June 1965, the two countries concluded a bilateral fishery agreement, while the settlement for the issue of sovereignty Takeshima/Dokdo was postponed until normalization of bilateral diplomatic relations is achieved. The 1965 fishery agreement established a 12-mile-wide exclusive fishery zone and a 40-mile-wide joint regulation zone from the coast of the Korean Peninsula. The joint regulation zone did not include the Takeshima/Dokdo islets themselves. The purpose of establishing these joint regulation zones was to regulate fishery by vessels flying the Japanese flag. ${ }^{11}$

\section{The dispute over maritime boundaries: from identifying common interests to the rise of nationalism}

Even the conclusion of the 1965 fishery agreement did not resolve bilateral tensions over Japanese fishery in the disputed area. However, the territorial dispute over Takeshima/Dokdo did not get primary attention during the Cold War period, as the Japan-ROK-U.S. solidarity had priority over the territorial dispute.

After the end of the Cold War, when the UN Convention on the Law of the Sea (UNCLOS) was ratified by both countries in $1996,{ }^{12}$ Japan and the ROK launched the government-level talks on amending the 1965 fishery agreement, seeking to delimit their overlapping exclusive economic zones. Disagreements on these zones rekindled the territorial dispute over Takeshima/Dokdo. While both sides agreed to conform to the equidistance principle for delimiting the border between their EEZs, they had different interpretations of baselines for measuring the breadth of the median line. ${ }^{13}$ The Republic of Korea categorized Dokdo as a rock ${ }^{14}$ and set the 200 nautical mile baseline at Ulleung Island, while proposing a median line between Ulleung and Oki. ${ }^{15}$ The Japanese side considered Takeshima as an island and insisted on using it as a reference point, thus proposing a median line between Takeshima and Ulleung. Eventually, both sides agreed to set provisional waters surrounding Takeshima/Dokdo without reference to their territorial sovereignty. In the new fishery agreement that was signed in November 1998 and came into force in January 1999 Japan and the ROK set two provisional waters areas in the Sea of Japan (Northern part of provisional waters) and in the East China sea (Fig. 1).

Under the new regime based on the 1998 agreement, the fishery zone between Japan and ROK is divided into two zones: the 200 nautical mile EEZ and provisional waters. Each state allows access to one"s own EEZ, determines a catch quota, and controls another state"s fishery vessels according to a domestic legal system in line with the coastal state principle. ${ }^{16}$ However, in provisional waters fishery vessels should be 
treated according to the flag state principle: a state is not eligible to apply its own laws to control another state"s fishing vessels. Under the flag state principle, states are eligible to control fishery vessels flying these states" own flags, in accordance with common rules regarding control over marine resources and fishery operations. Japan and the ROK agreed to have annual joint committee meetings on fishery issues to negotiate operational provisions in the EEZ and resource control in the provisional waters. ${ }^{17}$

Fig. 1. Provisional waters according to the 1998 Japan-ROK fisheries agreement

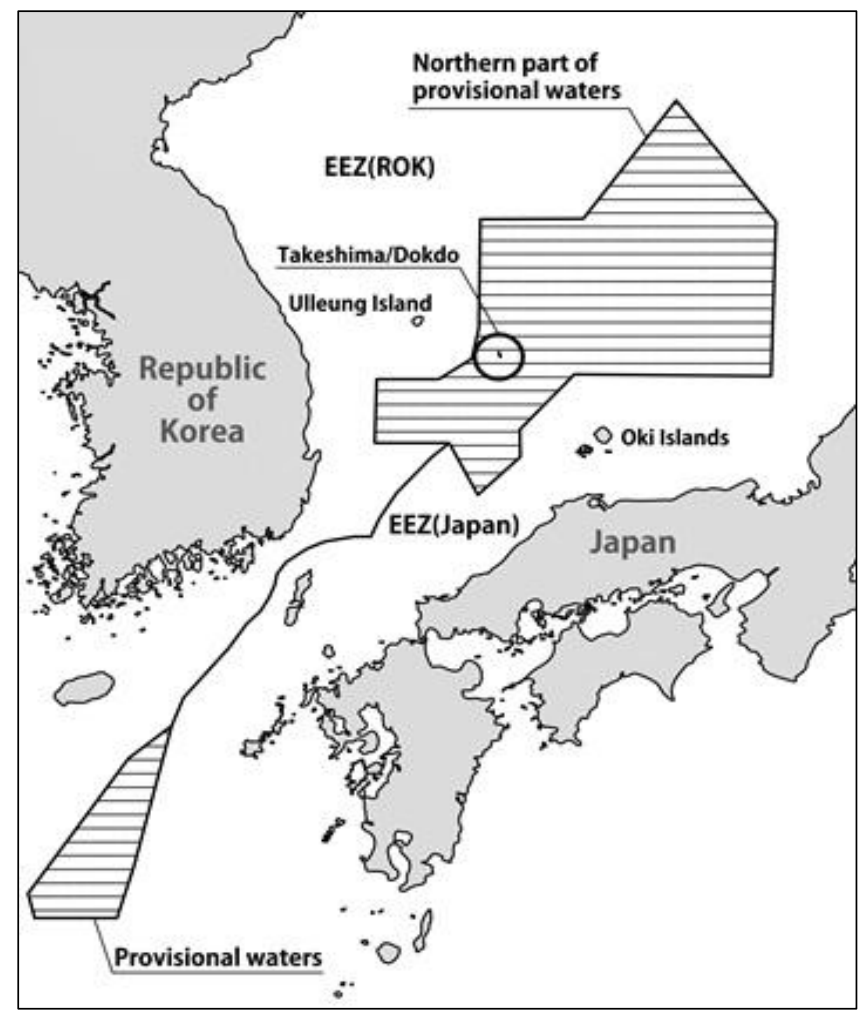

Source: Fishery Agency of Japan.

However, addressing contested issues under the auspices of the annual government-level joint committee did not progress as smoothly as local fishery operators expected. Both governments failed to reach a consensus about operational provisions in the EEZ in 2014 and 2016. Since the 2016 fishing season (July 2016 - June 2017), Japan and the ROK have not allowed mutual fishing access to each other"s exclusive economic zones. ${ }^{18}$ Japanese fishery operators have been disaffected with incorporation of a rich fishing ground ( $45 \%$ of the Yamatotai bank) and an area rich with snow crabs (Northern Oki and the Hamada triangle) into the provisional waters zone, taking into account that after conclusion of the 1998 agreement only South Korean fishing vessels utilized the former Japanese exclusive fishing grounds. ${ }^{19}$ For its part, the Korean public was critical of its own government that agreed to incorporate Dokdo into the provisional waters regime.

As discussed above, through the end of 1990s, the main issue of the territorial dispute was not so much sovereignty over Takeshima/Dokdo as delimitation of fishery grounds and fishery provisions. However, since the early 2000s, the dispute over Takeshima/Dokdo started to attract more attention than ever and has become a symbol of rising nationalism both in Japan and in the ROK. In March 2005, the Shimane Prefectural Assembly passed a law to designate 22 February as the "Takeshima Day", 
marking the centennial of having declared the islets as a part of the prefecture in 1905 . According to Article 1 of the ordinance, "residents of Shimane Prefecture, together with municipal governments and prefectural government establish the "Takeshima Day" in order to prompt the movement for ensuring the territorial sovereignty of Takeshima and to form public opinion regarding Takeshima". ${ }^{20}$ This local initiative was aggravated by the central government"s ambivalence on the issue of territorial sovereignty. During the Koizumi"s administration (April 2001 - September 2006), the Prime Minister"s visit to Yasukuni Shrine on the day marking the end of World War II provoked nationalistic feelings, although his government was reluctant to provoke confrontation with the ROK at the local revel. At the same time Korean vessels"aggressive and exclusive operations in provisional waters urged the public in the Shimane prefecture to demand that the central government make a more active diplomatic effort for re-establishing its territorial sovereignty over the ROK-controlled Takeshima. In turn, the ROK toughened its stance and, when bilateral negotiations on the delimitation of the EEZ resumed in June 2006, claimed that the 200 nautical miles baseline should be established at Dokdo. Thus, the territorial dispute over Takeshima/Dokdo became a central challenge for bilateral relations.

\section{The row between Japan and the ROK in the 2010s}

In the 2010s, bilateral relations between Japan and ROK went through ups and downs. They were influenced both by the historical perception gap between the two countries and by deteriorating international security environment related to the situation around North Korea. In this period, governments of the ROK used the territorial dispute for domestic political purposes. Specifically, President Lee Myung-bak"s landing on Takeshima/Dokdo on 10 August 2012 revealed his tough stance against Japan. The first visit to Takeshima/Dokdo by a leader of the ROK made the territorial dispute visible to the people of both countries, while previously, in a period since the conclusion of the 1965 Treaty on Basic Relations, both governments cautiously avoided exacerbating the conflict. ${ }^{21}$ Both Korean and Japanese journalists assumed that Lee tried to boost his popularity undermined by a corruption scandal. ${ }^{22}$ In any case, the visit incurred serious damage to bilateral relations. In response, Japanese Prime Minister Yoshihiko Noda strongly criticized Lee"s visit and recalled his country"s ambassador from Seoul.

Under the Park Geun-hye"s administration, the Japan-ROK relations temporarily improved after Tokyo and Seoul reached an agreement on the issue of the so-called comfort women at the bilateral Foreign Ministers" meeting on 28 December $2015 .{ }^{23} \mathrm{At}$ the Joint Press Occasion, Japan"s Foreign Minister Fumio Kishida stated on behalf of the government that the Prime Minister of Japan expressed again his most sincere apologies and remorse to all former comfort women. Most notably, both sides confirmed that this issue was resolved finally and irreversibly with this announcement. ${ }^{24}$ As serious differences in historical perceptions about the fate of Korean comfort women during World War II have been a longstanding obstacle in the Japan-ROK relations, some analysts believed that the 2015 agreement would remove the main impediment that had prevented the two countries from engaging diplomatically and cooperating on their shared security concerns. ${ }^{25}$ A year later, in November 2016, Japan and the ROK signed the General Security of Military Information Agreement (GSOMIA), the first military agreement between them. The agreement enables the two states to directly share classified military intelligence of second or lower degree, without the U.S. mediation. The relevant classified information includes those North Korea"s nuclear and ballistic missile activities that Seoul has limited capacity to monitor. ${ }^{26}$ In 2016 , North Korea conducted 
nuclear tests twice, in January and September. This demonstrated that the DPRK became a growing security threat to neighboring countries. The common threat from North Korea reminded Japan and the ROK of the necessity of close security cooperation at the government level. ${ }^{27}$ However, the signing of the GSOMIA drew a strong backlash from opposition parties and civic groups in the ROK. The agreement was concluded less than a month before Park was impeached by the National Assembly. ${ }^{28}$ The opposition groups accused Park and her government of concluding the agreement unilaterally without duly taking into account public sentiments against Japan"s unrepentant attitude toward its atrocities before and during World War II. ${ }^{29}$

Under President Moon Jae-in who took office in 2017, the Japan-ROK relations reached their lowest point since their normalization in 1965. As the president"s visit to Takeshima/Dokdo on July 25, 2016 demonstrated, he has taken a hardline stance on the territorial sovereignty dispute and interpretations of the historical past. Right after he took power, Moon set up a task force to review the controversial 2015 agreement, according to which Japan agreed to set up a foundation to support Korean comfort women and their families in return for ending the diplomatic row once and for all. ${ }^{30}$ In July 2018, the task force under the Moon administration concluded that the 2015 agreement failed to consider opinions of the victims of sexual slavery. The government allocated state budget funding to replace that from a Japanese foundation. ${ }^{31}$

On 30 October 2018, the Supreme Court of Korea ordered two Japanese firms to pay compensation to South Korean victims of wartime forced labor exploitation to satisfy their individual right for compensation. The Japanese government expressed its strong protest and argued that all problems concerning property, rights, and interests of the two parties, associated with Imperial Japan"s colonization of Korea in 1910-1945, were settled completely and finally by Article 2 of the 1965 Treaty on Basic Relations. ${ }^{32}$ The Statement by Foreign Minister Taro Kono, released on 28 November 2018, mentioned international adjudication and countermeasures in case the ROK does not take appropriate measures immediately. ${ }^{33}$

Bilateral relations seriously deteriorated in the course of 2019 , although both sides presented their settlement proposals, including the establishment of a tripartite foundation, proposed by a former ROK ambassador to Japan Shin Kak-su. ${ }^{34}$ On 20 May 2019, the Japanese government proposed to set up an arbitration panel composed of one representative of Japan, one of South Korea, and one from a third country; however, the ROK failed to appoint its representative by the deadline. Instead, the ROK proposed to hold discussions with Japan on condition that companies of the two countries contribute their funds to compensate South Korean victims, but the Japanese government did not approve this idea.

On 1 July 2019, the Ministry of Economy, Trade and Industry of Japan (METI) imposed export restrictions on fluorinated polyimide, resist, and hydrogen fluoride, and on related technologies needed to produce semiconductors. This step was justified by erosion of trust between the two countries and inadequate management of certain sensitive items by South Korean companies. ${ }^{35}$ Furthermore, on 2 August 2019, the Japanese government announced the removal of the ROK from the white countries list of the Export Trade Control Order. While the Japanese government officially announced that these measures were not related to the previous South Korean steps, the prevailing view in the ROK was that the Abe administration retaliated against Moon"s unyielding stance on the ruling on compensation. ${ }^{36}$ Economic retaliation by the Shinzo Abe"s government triggered a massive protest among the South Korean public. A growing number of people joined a boycott of Japanese apparel, travel products, and electronics in protest against Japan"s export control. ${ }^{37}$ 
South Korean government responded to Tokyo"s measures by removing Japan from its own white list of trade partners in August 2019. In addition, Seoul notified Japan that the ROK would not renew GSOMIA (which should be automatically renewed on 24 August every year). In this context, U.S. Secretary of State Mike Pompeo expressed his concern over the escalating Japan-ROK tensions and stressed high importance of cooperation on North Korea. ${ }^{38}$ In particular, U.S. officials were concerned about the fate of GSOMIA as a mechanism that facilitated three-way intelligence exchange between the USA, Japan, and the ROK on the North Korean nuclear and missile threat.

Thus, in the 2010s, the Japan-ROK row concerning territorial sovereignty over Takeshima/Dokdo has led to deterioration of political relations between the two countries. Furthermore, political confrontation between Japan and the ROK rapidly expanded to a trade war and endangered the renewal of military-intelligence agreement, which is a linchpin of the U.S.-led alliance in this region. Against this background, visits to Takeshima/Dokdo by South Korean parliamentarians and tourists have increased since 2012 (with the exception of 2014 and 2015, marked by the Sewol ferry incident and the MERS epidemic). ${ }^{39}$

\section{The 2019 Russian-Chinese air patrol over Takeshima/Dokdo}

On 23 July 2019, when the export control dispute was in full bloom, South Korea reported that a Russian warplane violated its airspace above the East Sea (Sea of Japan) near Dokdo islets, provoking the ROK Air Force to fire a warning shot. ${ }^{40}$ According to Seoul, the incident came right after two Tu-95 Russian bombers and two Chinese $\mathrm{H}-6$ aircraft entered the South Korean air defense identification zone (KADIZ) without prior notice and when the two Russian bombers again trespassed on the air defense zone in the afternoon. ${ }^{41}$ According to the South Korean media, this was the first time when a foreign military plane violated the country"s territorial sky and when South Korea responded with warning shots. ${ }^{42}$ Also, it was the first time when Russian and Chinese aircraft entered the KADIZ simultaneously. On that day, the Foreign Ministry of the ROK summoned acting Russian Deputy Chief of Mission Maxim Volkov and Deputy Foreign Minister Yoon Soon-gu delivered a strong protest against violation of the ROK"s airspace. Also, Director of Cheong Wa Dae"s National Security Office Chung Eui-yong requested Russian Secretary of the Security Council Nikolai Patrushev to take appropriate measures. ${ }^{43}$ The ROK also summoned Chinese Ambassador Qiu Guohong to deliver warning for his state. ${ }^{44}$

This incident revealed that sovereignty disputes in the region concern not only over the islets and marine resources, but also the airspace over Takeshima/Dokdo. The air area that the Russian and Chinese bombers entered simultaneously on July 23 includes an overlapping air area of Chinese, Japanese, and ROK"s ADIZ. While Japan claims territorial sovereignty of Takeshima, it does not include the airspace above the islets in its ADIZ. Japan protested through diplomatic channels against both Russia"s airspace violation and the ROK"s warning shot. ${ }^{45}$ According to Chief Cabinet Secretary Yoshihde Suga, Japan urged Russia not to repeat this airspace violation. The ROK responded that it cannot accept the Japanese statement because the islets belong to South Korea. ${ }^{46}$

In the evening of 23 July, the Russian Defense Ministry announced that earlier that day Russia"s Aerospace Force and China"s Air Force carried out their joint air patrol in the Asia-Pacific region for the first time ${ }^{47}$ as a part of implementing provisions of the Russia-China 2019 bilateral plan for military cooperation. As for the incident, the Russian Defense Ministry stressed that the joint patrol was not directed against third countries and claimed that other countries" borders were not violated. ${ }^{48}$ In Moscow, a military attaché of 
the ROK was summoned and received a protest against illegal and dangerous behavior by those South Korean pilots who crossed the flight route of the Russian Tu-95 MS. ${ }^{49}$ Russia"s reaction demonstrates that it does not recognize other states"claims to establish their ADIZ. It should also be noted that Russia officially expressed objection to the ROK"S protest and left the Japanese claim unanswered.

So far, there is no credible evidence to determine whether it was an unplanned accident or a special operation managed by the Russian Ministry of Defense. In any case, the fact that the incident occurred in the Takeshima/Dokdo area raised the Japanese, South Korean, and U.S. concerns about the potential threat from the Sino-Russian joint military operations in this region. In a month, the ROK conducted a two-day military exercise on and around Dokdo. The military exercise was the first of that year"s two regular drills and the number of troops involved was nearly twice as large as that of the previous one. ${ }^{50}$

The incident occurred at the time of emerging split within the ROK-Japan-USA military intelligence alliance, whereas Chinese and Russian defense officials agreed to start talks on a new military deal, to update their 1993 military cooperation agreement. ${ }^{51}$ While the Chinese government made a restrained media response to the incident, ${ }^{52}$ Russian comments were more assertive. According to an article from the Ministry of Defense"s official newspaper "Krasnaia zvezda", Russia did not recognize the KADIZ as the latter had no legal basis and, thereby, Russian warplanes would keep flying in accordance with international rules. ${ }^{53}$ Vasili Kashin, an expert on the Russia-China military cooperation, pointed out that Russia"s involvement in military operations in the Pacific alongside Chinese counterparts casts the prospects of a possible conflict in the region in a different light. He maintained that this development significantly increases the People Liberation Army"s striking capabilities, which would, in turn, require the United States to make certain costly steps in response. ${ }^{54}$ Against this background, the regional security order promoted by the United States, the ROK and Japan now appears to be tested by both internal fissures and outside pressures from Russia and China.

\section{Conclusions}

The ROK has dealt with the Takeshima/Dokdo issue both as a territorial dispute and as a historical problem associated with the Japanese colonial control of Korea. For Japan (that does not de facto control the islets), the Takeshima/Dokdo issue since the end of the World War II has been closely linked to the issue of fishery rights in the Sea of Japan. As discussed in the third section, after the UNCLOS came into force in 1994, the ROK and Japan signed a new fishery agreement in 1998 and sought to form a new marine order based on common interests, i. e. joint peaceful use of the sea and control over the marine resources. However, it proved hard to ensure effective control over illegal fishery vessels and fishing quotas in the northern part of the provisional waters zone around Takeshima/Dokdo. In the late 1990s - early 2000s, the main focus on the Takeshima/Dokdo issue changed from fishery to the local nationalism perspectives on territorial sovereignty over the islets.

A specific feature of a maritime border is that disputed maritime areas are hidden from most of the people who live in the mainland. The general public is rarely sensitive to the issues of distant border islets. However, following Lee Myung-bak"s first visit to Dokdo in August 2012, mass media started to regularly cover subsequent visits to Dokdo by South Korean politicians and lawmakers. This helped visualize the dispute and triggered the rise of nationalist sentiments both in the ROK and Japan.

In addition to the fishery agreement, Japan and the ROK shared an interest in 
dealing with the common military threat from North Korea. The two countries concluded their first military agreement, the GSOMIA, in November 2015. This agreement facilitated intelligence sharing among the ROK, Japan, and the United States on North Korea"s activities. However, cooperation was undermined by the escalation of the Japan-ROK row over the wartime forced labor issue. Thus, by the early 2020s, the Japan-ROK confrontation has evolved from the territorial sovereignty dispute over Takeshima/Dokdo to a multidimensional conflict that involves the historical perception gap, a trade war, a failure of the fishery agreement, and renewed problems with the military-intelligence agreement. The latter issue may have a serious effect on regional security order in Northeast Asia. As discussed in section V, the July 2019 airspace/ADIZ incident revealed that an unsettled maritime border issue could trigger competition for sovereignty not only over the islets and marine resources, but also, in the absence of common international legal framework, over airspace and air defense identification zones.

\section{ENDNOTES}

\footnotetext{
1 From a neutral standpoint, the islets are sometimes called the "Liancourt Rocks" in English.

2 Блинов М. МИД разъяснил ситуацию с договором с США о Беринговом проливе // РИА Новости. 27.01.2020. URL: https://ria.ru/20200127/1563921580.html?in=t.
}

${ }^{3}$ Bull H. The Anarchical Society: A Study of Order in World Politics. - N.Y.: Palgrave MacMillan, 2002. P. 13.

4 Ibid. P. 8.

5 This descriptive section is based on information from the official websites of the two states' Ministries of Foreign Affairs. Ministry of Foreign Affairs of Japan. URL: https://www.mofa.go.jp/region/asia-paci/ takeshima/index.html; Ministry of Foreign Affairs. Republic of Korea. URL: http://dokdo.mofa.go.kr/eng.

6 Residents include 1 civilian, 35 police personnel (coast guards), 2 Dokdo lighthouse managers, and 2 Dokdo office staffs. Residents \& Visitors. Ministry of Foreign Affairs. Republic of Korea.

URL: http://dokdo.mofa.go.kr/eng/introduce/residence.jsp.

7 Hamada T., Sasaki T. Gyogyō to kokkyō [Fishery and Border]. - Tokyo: Misuzu shobo, 2020. P. 55.

8 Ibid. P. 173.

9 Establishment of "Syngman Rhee Line" and illegal occupation of Takeshima by the Republic of Korea. Ministry of Foreign Affairs of Japan, 30 July 2015. URL: https://www.mofa.go.jp/a_o/ natakeshima/page1we_000064.html.

10 This number is based on the open-access source in the official website of Shimane prefecture. Sugihara T. "Iwami taimuzu" ga kataru ri shōban rain [The Syngman Rhee Line described in the local newspaper "Iwami Times"]. Web Takeshima Issue Research. URL: https://www.pref.shimane.Ig.jp/ admin/pref/takeshima/web-takeshima/takeshima04/takeshima04-1/takeshima-042401.html.

11 Hamada T., Sasaki T. Op. cit. P. 180.

12 The UN Convention on the Law of the Sea (UNCLOS) came into force in 1994. It set up 12 nautical miles limit for territorial waters and 200 nautical miles for exclusive economic zones. The Republic of Korea ratified the convention in January 1996, China and Japan - in June 1996, Russia - in March 1997. With ratification of UNCLOS, problems of overlapping neighbor countries" EEZ mounted. To manage the issue, the framework of "provisional waters" that applied only for vessels of those countries that have overlapping claims was established. The Japanese government signed the bilateral fisheries agreements based on this principle with China (1997), the Republic of Korea (1998), 
and Russia (1998). For more detail, see: Iwashita A. Japan"s Border Issues: Pitfalls and Prospects. Abingdon: Routledge, 2016. P. 17-19.

${ }^{13}$ According to Article 15 of the UNCLOS: "Where the coasts of two States are opposite or adjacent to each other, neither of the two States is entitles, failing agreement between them to the contrary, to extend its territorial sea beyond the median line every point of which is equidistance from the nearest points on the baselines from which the breadth of the territorial seas of each of two States is measured." United Nations Convention on the Law of the Sea. URL: https://www.un.org/depts/los/ convention_agreements/texts/unclos/unclos_e.pdf.

${ }^{14}$ According to Article 121 of the UNCLOS, "rocks which cannot sustain human habitation or economic life of their own shall have no exclusive economic zone or continental shelf".

15 Iwashita A. Op. cit. P. 89-90.

${ }^{16}$ Nikkan gyogyō kyōtei no gaiyō. Heisei 10 nen 11 gatsu 28 nichi shomei, Heisei 11 nen 1 gatsu 22 nichi hakkō [Summary of Japan-ROK fishery agreement, signed 28 November 1998, came into force on 22 January 1999]. Fishery Agency of Japan. URL: https://www.jfa.maff.go.jp/j/press/kokusai/pdf/ 160523-01.pdf.

17 Ibid.

${ }^{18}$ Heisei 30 nendo Suisan no dōkō, Reiwa gan nendo suisan sisaku [FY 2018 trends in fisheries, FY 2019 fisheries policy, White Paper on fisheries]. Fishery Agency of Japan.

URL: https://www.jfa.maff.go.jp/j/kikaku/wpaper/index.html. P. 139-140.

19 Iwashita A. Op. cit. P. 90-91.

20 Takeshimanohi wo sadameru jourei [The Prefectural Ordinance designating Takeshima Day]. Shimane Prefectural Government. 16.03.2005. URL: https://www.pref.shimane.lg.jp/gikai/ugoki/ takesima/takesima.data/jyourei.pdf.

${ }^{21}$ Nakagawa M. Nikkan kankei no gyaku kōsu [Reverse course in Japan-ROK relations] // IDE Sukuea-Kaigai Kenkyuin report. November 2019. URL: https://www.ide.go.jp/Japanese/IDEsquare/ Overseas/2019/ISQ201930_013.html.

${ }^{22}$ Harlan Ch. S. Korean President visits islets at center of territorial dispute with Japan // The Washington Post. 10.08.2012.

${ }^{23}$ Announcement by Foreign Ministers of Japan and the Republic of Korea at the Joint Press Occasion. Ministry of Foreign Affairs of Japan. 28.12.2015. URL: https://www.mofa.go.jp/a_o/na/kr/ page4e_000364.html.

${ }^{24}$ Ibid.

25 Tatsumi Yu. Japan, South Korea reach agreement on "comfort women" // The Diplomat. 28.12.2015. URL: https://thediplomat.com/2015/12/japan-south-korea-reach-agreement-on-comfort-women.

${ }^{26}$ Yi E.-W. Seoul, Tokyo sign disputes military intelligence-sharing pact // The Korea Times. 23.11.2016.

${ }^{27}$ Ibid.

${ }^{28}$ In November 2016, Park asked the South Korean Parliament to decide how and when she should give up power over the scandal that her top aid, Choi Soon-sil"s inappropriate influence of state affairs. On 10 March 2017, Constitutional Court upheld the Parliament"s vote to impeach Park, thereby removing her from office.

${ }^{29}$ Yi E.-W. Op. cit 
30 S.Korea approves budget to replace Japanese fund over wartime sex slaves // Yonhap News Agency. 24.07.2018. URL: https://en.yna.co.kr/view/AEN20180724003300315?section=search.

31 Ibid. In July 2019, the foundation dedicated to the surviving victims was disbanded.

32 Regarding the decision by the Supreme Court of the Republic of Korea, confirming the existing judgements on Japanese company (statement by Foreign Minister Taro Kono). Ministry of Foreign Affairs of Japan. 29.11.2018. URL: https://www.mofa.go.jp/press/release/press4e_002242.html.

33 Ibid.

34 Shin Kak-su proposed to establish a tripartite foundation with participation of the government of ROK, related Korean firms, and those Japanese firms which hired labor force during the World War II. Kankoku no moto chunichitaishi ga toku "sansha kikin an" [Former South Korea"s Ambassador to Japan explains an idea of "tripartite foundation"] // Asahi Shimbun. 01.12.2018.

URL: https://digital.asahi.com/articles/ASLCZ5Q74LCZUHBI027.html?iref=pc_ss_date.

35 Update of METI"s licensing policies and procedures on exports of controlled items to the Republic of Korea. Ministry of Economics, Trade and Industry of Japan. 01.07.2019. URL: https://www.meti.go.jp/ english/press/2019/0701_001.html.

36 Lee Ch.-D. Seoul-Tokyo relations at risk after Japan"s retaliatory step // Yonhap News Agency. 19.07.2019. URL: https://en.yna.co.kr/view/AEN20190719004100315.

37 Ibid.

38 Shin H. South Korea-Japan talks falter ahead of decision on favored-trade list // Reuters. 01.08.2019. URL: https://www.reuters.com/article/us-southkorea-japan/south-korea-japan-talks-falterahead-of-decision-on-favored-trade-list-idUSKCN1UR39K.

39 In 2018, South Korea"s lawmakers' group landed on Takeshima Dokdo three times in May, October, and November. Also, over 200000 tourists join the Dokdo tour annually. From January to November 2018, 221056 people landed at Dokdo or joined the cruising tour around Dokdo, a $7.3 \%$ increase compared to the previous year. Kotoshi no dokudo homonsha 22mannin chō: zennenhi 1.5man nin zō [This year"s visitors to Dokdo exceeded 220 thousand: 15 thousand increase year on year] // Yonhap News Agency. 12.12.2018. URL: https://jp.yna.co.kr/view/AJP20181212004300882?section=search.

40 Oh S.-M. Russian aircraft violates S.Korea"s airspace above East Sea twice // Yonhap News Agency. 23.07.2019. URL: https://en.yna.co.kr/view/AEN20190723005456325?section=searchOh.

41 Ibid.

42 Ibid.

43 Jung D.-M. South Korea warns Russia strongly over airspace violation // The Korea Times. 23.07.2019.

44 Ibid.

45 Ito Yo., Kamiya T., Ishibashi R. Churo gun yonki, Tsushima kaikyōjōkū no bōkūshikibetsuken shinnyu kyōdōkanshi ka [Four Chinese and Russian Bombers Entered the ADIZ over the Tsushima Strait: a Joint Surveillance?] // Asahi Shimbun, 23.07.2019. URL: https://digital.asahi.com/articles/ ASM7R6K82M7RUHBI029.html.

46 Russia wants probe on alleged S. Korean airspace violation // Asahi Shimbun. 24.07.2019. URL: http://www.asahi.com/ajw/articles/13060847.

47 Что известно об инциденте с самолетами РФ и Южной Кореи над Японским морем // ТАСС. 
23.07.2019. URL: https://tass.ru/mezhdunarodnaya-panorama/6691974.

${ }^{48}$ According to several media sources, Russia seemingly changed its attitude toward the incident over a short period of time. The chairman of the South Korean Parliament"s Foreign Affairs Committee Yoon Sang-hyun said that Maxim Volkov told him Russia "regrets" the incident. However, Russia"s Embassy of Seoul could not immediately confirm Volkov"s comments. See: Russia wants probe on alleged S. Korean airspace violation. Op. cit.

48 Что известно об инциденте с самолетами РФ и Южной Кореи над Японским морем. Ук. соч.

49 Ibid.

50 Oh S.-M. S.Korea wraps up expanded military drills for Dokdo // Yonhap News Agency. 26.08.2016. URL: https://en.yna.co.kr/view/AEN20190826000251325?section=search.

${ }^{51}$ Никольский А., Сафонов И. Москва и Пекин обновляют соглашение о военном сотрудничестве // Ведомости. 23.07.2019. URL: https://www.vedomosti.ru/politics/articles/2019/07/23/807055moskva-pekin.

52 Beijing announced that the joint air patrol was a cooperative activity implemented as part of epy 2019 military cooperation plan. Минобороны Китая заявило, что продолжит совместные операции с Россией // TACC. 24.07.2019. URL: https://tass.ru/mezhdunarodnaya-panorama/6695707.

53 Подзоров Е. Впервые лѐтчики двух стран вместе патрулировали над Тихим океаном // Красная звезда. 24.07.2019. URL: http://redstar.ru/vpervye-rossijskie-i-kitajskie-lyotchiki-sovmestnopatrulirovali-nad-tihim-okeanom/?attempt=1.

${ }^{54}$ Kashin V. Joint Russian-Chinese air patrol signifies new level of cooperation. Carnegie Moscow Center. 30.07.2019. URL: https://carnegie.ru/commentary/79587.

\section{BIBLIOGRAPHY}

1. Announcement by Foreign Ministers of Japan and the Republic of Korea at the Joint Press Occasion. Ministry of Foreign Affairs of Japan. 28.12.2015.

URL: https://www.mofa.go.jp/a_o/na/kr/page4e_000364.html.

2. Blinov M. MID raziasnil situatsiiu s dogovorom S SSHA o Beringovom prolive // RIA Novosti. 27.01.2020. URL: https://ria.ru/20200127/1563921580.html?in=t.

Блинов М. МИД разъяснил ситуацию с договором с США о Беринговом проливе // РИА Новости. 27.01.2020. URL: https://ria.ru/20200127/1563921580.html?in=t.

3. Bull $\mathrm{H}$. The anarchical society: a study of order in world politics. - N.Y.: Palgrave MacMillan, 2002.

4. Chto izvestno ob intsidente s samoletami RF i luzhnoi Korei nad laponskim morem // TASS. 23.07.2019. URL: https://tass.ru/mezhdunarodnaya-panorama/6691974.

Что известно об инциденте с самолетами РФ и Южной Кореи над Японским морем // TACC. 23.07.2019. URL: https://tass.ru/mezhdunarodnaya-panorama/6691974.

5. Establishment of "Syngman Rhee Line" and illegal occupation of Takeshima by the Republic of Korea. Ministry of Foreign Affairs of Japan. URL: https://www.mofa.go.jp/ a_o/na/takeshima/page1we_000064.html.

6. Hamada T. and Sasaki T. Gyogyō to kokkyō [Fishery and Border]. - Tokyo: Misuzu shobo, 2020.

7. Harlan Ch. S. Korean President visits islets at center of territorial dispute with Japan // The Washington Post. 10.08.2012. URL: https://www.washingtonpost.com/world/ s-korean-president-visits-islets-at-center-of-territorial-dispute-with-japan/2012/08/10/513 abbc2-e2d5-11e1-a25e-15067bb31849_story.html. 
8. Heisei 30 nendo Suisan no dōkō, Reiwa gan nendo suisan sisaku [FY 2018 trends in fisheries, FY 2019 fisheries policy, White Paper on fisheries]. Fishery Agency of Japan. URL: https://www.jfa.maff.go.jp/j/kikaku/wpaper/index.html.

9. Ito Yo., Kamiya T., Ishibashi R. Churo gun yonki, Tsushima kaikyōjōkū no bōkūshikibetsuken shinnyu kyōdōkanshi ka [Four Chinese and Russian Bombers Entered the ADIZ over the Tsushima Strait: a Joint Surveillance?] // Asahi Shimbun. 23.07.2019.

URL: https://digital.asahi.com/articles/ASM7R6K82M7R UH BI029.html.

10. Iwashita A. Japan"s Border Issues: Pitfalls and Prospects. - Abingdon: Routledge, 2016.

11. Jung D.-M. South Korea warns Russia strongly over airspace violation // The Korea Times. 23.07.2019. URL: https://www.koreatimes.co.kr/www/nation/2020/01/205_272 755.html\#.

12. Kankoku no moto chunichitaishi ga toku "sansha kikin an" [Former South Korea"s Ambassador to Japan explains an idea of "tripartite foundation"] // Asahi Shimbun. 01.12.2018. URL: https://digital.asahi.com/articles/ASLCZ5Q74LCZUHBI027.html?iref =pc_ss_date.

13. Kashin $\mathrm{V}$. Joint Russian-Chinese air patrol signifies new level of cooperation. Carnegie Moscow Center. 30.07.2019. URL: https://carnegie.ru/commentary/79587.

14. Kotoshi no dokudo homonsha 22mannin chō: zennenhi 1.5man nin zō [This year"s visitors to Dokdo exceeded 220 thousand: 15 thousand increase year on year] // Yonhap News Agency. 12.12.2018. URL: https://jp.yna.co.kr/view/AJP20181212004300882? section=search.

15. Lee Ch.-D. Seoul-Tokyo relations at risk after Japan"s retaliatory step // Yonhap News Agency, 19.07.2019. URL: https://en.yna.co.kr/view/AEN20190719 004100315.

16. Minoborony Kitaia zaiavilo, chto prodolzhit sovmestnye operatsii s Rossiei // TASS. 24.07.2019. URL: https://tass.ru/mezhdunarodnaya-panorama/6695707.

Минобороны Китая заявило, что продолжит совместные операции с Россией // TACC. 24.07.2019. URL: https://tass.ru/mezhdunarodnaya-panorama/6695707.

17. Nakagawa M. Nikkan kankei no gyaku kōsu [Reverse course in Japan-ROK relations] // IDE Sukuea-Kaigai Kenkyuin report. November 2019. URL: https://www.ide.go.jp/ Japanese/IDEsquare/Overseas/2019/ISQ201930_013.html.

18. Nikkan gyogyō kyōtei no gaiyō. Heisei 10 nen 11 gatsu 28 nichi shomei, Heisei 11 nen 1 gatsu 22 nichi hakkō [Summary of Japan-ROK fishery agreement, signed 28 November 1998, came into force on 22 January 1999]. Fishery Agency of Japan.

URL: https://www.jfa.maff.go.jp/j/press/kokusai/pdf/160523-01.pdf.

19. Nikol'skii A., Safonov I. Moskva i Pekin obnovliaiut soglashenie o voennom sotrudnichestve // Vedomosti. 23.07.2019. URL: https://www.vedomosti.ru/politics/ articles/2019/07/23/807055-moskva-pekin.

Никольский А., Сафонов И. Москва и Пекин обновляют соглашение о военном сотрудничестве // Ведомости. 23.07.2019. URL: https://www.vedomosti.ru/politics/ articles/2019/07/23/807055-moskva-pekin.

20. Oh S.-M. Russian aircraft violates S. Korea"s airspace above East Sea twice // Yonhap News Agency. 23.07.2019. URL: https://en.yna.co.kr/view/AEN20190723005456325? section=searchOh.

21. Oh S.-M. S. Korea wraps up expanded military drills for Dokdo // Yonhap News Agency. 26.08.2016. URL: https://en.yna.co.kr/view/AEN20190826000251325?section=search.

22. Podzorov E. Vpervye lyotchiki dvuh stran vmeste patrulirovat' nad Tihim okeanom // Krasnaia zvezda. 24.07.2019. URL: http://redstar.ru/vpervye-rossijskie-i-kitajskielyotchiki-sovmestno-patrulirovali-nad-tihim-okeanom/?attempt=1.

Подзоров Е. Впервые лѐтчики двух стран вместе патрулировали над Тихим океаном // Красная звезда. 24.07.2019. URL: http://redstar.ru/vpervye-rossijskie-i- 
kitajskie-lyotchiki-sovmestno-patrulirovali-nad-tihim-okeanom/?attempt=1.

23. Regarding the decision by the Supreme Court of the Republic of Korea, confirming the existing judgements on Japanese company (statement by Foreign Minister Taro Kono). Ministry of Foreign Affairs of Japan. 29.11.2018. URL: https://www.mofa.go.jp/ press/release/press4e_002242.html.

24. Residents \& Visitors. Ministry of Foreign Affairs. Republic of Korea.

URL: http://dokdo.mofa.go.kr/eng/introduce/residence.jsp.

25. Russia wants probe on alleged S.Korean airspace violation // Asahi Shimbun. 24.07.2019. URL: http://www.asahi.com/ajw/articles/13060847.

26. S.Korea approves budget to replace Japanese fund over wartime sex slaves // Yonhap News Agency 24.07.2018. URL: https://en.yna.co.kr/view/AEN20180724003300315? section=search.

27. Shin H. South Korea-Japan talks falter ahead of decision on favored-trade list // Reuters, 01.08.2019. URL: https://www.reuters.com/article/us-southkorea-japan/south-koreajapan-talks-falter-ahead-of-decision-on-favored-trade-list-idUSKCN1UR39K.

28. Sugihara T. "Iwami taimuzu" ga kataru ri shōban rain // Web Takeshima Issue Research. URL: https://www.pref.shimane.lg.jp/admin/pref/takeshima/web-takeshima/takeshima04 /takeshima04-1/takeshima-042401.html.

29. Takeshimanohi wo sadameru jourei [The Prefectural Ordinance designating Takeshima Day] // Shimane Prefectural Government. 16.03.2005. URL: https://www.pref.shimane. lg.jp/gikai/ugoki/takesima/takesima.data/jyourei.pdf.

30. Tatsumi Yu. Japan, South Korea reach agreement on "comfort women" // The Diplomat. 28.12.2015. URL: https://thediplomat.com/2015/12/japan-south-korea-reach-agreement -on-comfort-women.

31. Update of METI"s licensing policies and procedures on exports of controlled items to the Republic of Korea. Ministry of Economics, Trade and Industry of Japan. 01.07.2019. URL: https://www.meti.go.jp/english/press/2019/0701_001.html.

32. Yi E.-W. Seoul, Tokyo sign disputes military intelligence-sharing pact // The Korea Times. 23.11.2016. URL: https://www.koreatimes.co.kr/www/nation/2018/07/205_218792.html. 